\title{
THE ANALYSIS OF ECONOMIC VALUE ON IRRIGATION UTILIZATIONATRICE FARMING IN BUAHDUA DISTRICT, SUMEDANG REGENCY, WEST JAVA
}

\author{
Ulfah Suci Amalia ${ }^{1)}$ Ernah $^{1)}$ \\ ${ }^{1)}$ Department of Social Economics, Faculty of Agriculture, Padjadjaran University, Indonesia \\ Ulfahsuciamalia@yahoo.com, ernah@unpad.ac.id
}

\begin{abstract}
Water is a main factor on production input in rice farming. The need for water will increase as time progresses, but the availability of it is increasingly uncertain. One way to overcome the scarcity of water is the efficient using of water by determining the price of irrigation. This study aims to determine the price of water which is probably paid by farmers in rice farming, and to know the constraints faced by them. The research design used is quantitative descriptive. Primary data are obtained from 80 farmers taken by simple random sampling. Data analysis' used here are analysis of descriptive, analysis of farming, and analysis of Willingness To Pay (WTP). The result of this research shows that the value of water rent in Buahdua Village is Rp. 4,428,031/ha/MT. Interviews show that almost all farmers are willing to pay the price of irrigation. The average value of PAP respondent is Rp. 61,813/ha/MT and the average value of TWTP is Rp. 28,751.891. Many obstacles faced by farmers in the use of irrigation is garbage, difficulty of getting water during the dry season, and damaged irrigation. This condition will affect the increasingly inefficient management of irrigation. Therefore, the economic value of water usage can be used as a reference asafees level by the farmers to reach efficiently.
\end{abstract}

Keywords: Farming, Rice Field, Water Rent, Irrigation, Willingness To Pay (WTP).

\section{INTRODUCTION}

The agricultural sector is one of the sectors that require water resources, the availability of water is a very important element and become one of the success keys in the implementation of agricultural processes to support productivity, where some water resources are used as irrigation water. The role of irrigation is very important in the field of rice farming as one of the keys to success in the implementation of the farming process in order to support productivity. With the increasing population of Indonesia, the need for irrigation water to produce paddy rice will also increase.

Buahdua sub-district is the second sub-district that produces the largest rice production in Sumedang Regency, and has good agricultural potential, where the amount of rice field production is approximately 42 thousand with the land area is 2,976 ha (BPS, 2015). However, the irrigation system is still simple and only managed by the group. At this time the use of water has not been charged so that the treatment is still simple.

Irrigation water is a public good so the usage is less efficient both in the rainy season and dry season. Water is considered as the resource that can be exploited, despite the fact that it has a limited amount. As irrigation water users grow, efficiency is critical. Implementing the price/value of irrigation water use can be one of the ways in water use efficiency. 
Buahdua village is a village that has not set the price/value of irrigation water use, public opinion about water which is nature goods that is free to use and will always be abundant become one of the factors on the absence of irrigation water price determination. But now, sometimes there is a shortage of water in several blocks of rice fields because there is no source of springs. This is a problem because many farmers cheat by clogging water channels to other farmers' land. Based on the above background, this study focused on the topic of economic value analysis of irrigation water use in rice farming in Buahdua subdistrict Sumedang Regency, West Java.

The aims of this study are to :

1. Know the characteristics of paddy rice farmers in Buahdua Sub-district, Sumedang Regency.

2. How is the contribution of water to rice field farming in Buahdua Subdistrict, Sumedang Regency?

3. What is the price of water that can be paid by farmers in rice field farming in Buahdua Subdistrict, Sumedang Regency?

\section{RESEARCH METHODS}

Research Location. This research was conducted in Buahdua Village, Buahdua Subdistrict, Sumedang Regency, West Java. The site of the study was chosen with consideration of the amount of rice production, a simple irrigation system, no organization specifically in managing water, and no paid irrigation.

Research Design and Data Analysis. The research design used quantitative descriptive, while data analysis used descriptive analysis, analysis of farming, and analysis of Willingness To Pay (WTP). Data collection methods were observation, interview, questionnaire and literature study.

Respondent Sampling. The sample in this research, researchers used probability sampling with simple random sampling type. Determination of farmer samples was performed by using the Slovin formula (Umar, 2003), which resulted in the total number of sample members as many as 80 respondents from the population of 412 .

Data Analysis. Data analysis used descriptive analysis to describe characteristic of paddy rice farmers in Buahdua Village, Buahdua Subdistrict, Sumedang Regency, for water rent analysis used farming analysis without inclusion of irrigation value with formula:

$$
\mathrm{WR}=\mathrm{TR}-\mathrm{TC}
$$

Where WR is a water rent, TR is a Total Revenue and TC is Total Cost (farm production costs). Farming revenue (TR) is the multiplication of the obtained production with the selling price which can be written as follows:

$$
\mathrm{TR}=\mathrm{Y} . \mathrm{Py} \text {. }
$$

Where TR is the total revenue of rice field farming, $\mathrm{Y}$ is the amount of production output which obtained from rice field farming and $\mathrm{Py}$ is the output production price of rice field farming. While to calculate farm production costs can be written as follows:

$$
\mathrm{TC}=\mathrm{X} \cdot \mathrm{PX}
$$

Where TC is the total production cost of rice field farming, $\mathrm{X}$ is the number of inputs used for rice field farming, and Px is the input price of rice field farming except irrigation water fees.

Analysis of Willingness To Pay (WTP) is used to analyze the willingness of farmers to pay or spend money for the maintenance of irrigation networks. Therefore it can be obtained the value of WTP from each respondent of rice farmers. Furthermore, it can be calculated the average estimate of WTP (EWTP) by using the middle value of the class or interval of PI of respondent $i$. The estimated average of WTP can be calculated by the formula:

$$
\mathrm{EWTP}=\sum_{i=1}^{n} W i P f i
$$

Where EWTP is a guessed average of WTP, Wi is the lower bound of the WTP 
class, Pfi is the relative frequency of the class in question, $\mathrm{n}$ is the number of classes (interval), and $i$ is the class order of $i$.

To determine aggregate of WTP can be calculated by the formula:

$$
\mathrm{TWTP}=\sum_{i=1}^{n} W T P i\left[\frac{n i}{N}\right] P .
$$

Where the TWTP is the willingness of the farmer population to pay, the WTPi is the willingness of the respondent to pay, ni is the sum of the sample land of the $i$ who pays for the WTP, N represents the total area of sample land, and $\mathrm{P}$ represents the total land area of the population.

\section{RESULTS AND DISCUSSION}

Condition of Agriculture and Irigation System .The total area of rice field in Buahdua Village is 196.4 ha with overall rice field used simple irrigation type. Usually, farmers and farm laborers inherit the hereditary skills of their family in the rice field farming. Most farmers are subsistence farmers where the farmed yields are used to fulfill the daily life of the family and if there is any residue then the crop can be sold.

Most of them, $63 \%$ of farmers respondents are doing rice farming activities in 3 times of planting season, and as many as $37 \%$ of farmers respondents only do rice farming in 2 times of planting seasons, for the dry season they plant palawija so the land still can be cultivated and income still exist even though not many as rice farming.

Buahdua village does not have its own springs but the water is always there in every season, there are only a few places that lack water in the dry season. Special irrigation channels and irrigation schedules are created to address the problem. Every 2 weeks, every block is irrigated by water from Panyindangan Village. There is another problem which is always complained by farmers that is irrigation channels are broken. This happens because the not optimal irrigation channel execution that was performed by third parties, consequently the flow of water into the rice field is quite small.

As many as $56 \%$ of respondents said the condition of the irrigation network that flows into their land was good, but $41 \%$ said that the network condition was less good even there were $6 \%$ of respondents who said it was not good. Farmers complained that the irrigation channels that drain the water to many fields were damaged and there was enough disturbing waste so that the flow of water that flows became small. This condition make farmers confused where they go to complain. They can only repair and clean the irrigation channels with simple method every time they enter the planting period.

\section{History of Irigation Water Manager}

Organization. Buahdua village has not yet to have an organization that specializes in managing irrigation networks such as P3A (Farmers Union of Water Users) so that every irrigation is still managed by farmer groups. Formerly in the village of Buahdua, there are ulu-ulu that help Ekbang. Ulu-ulu is part of a village that has the task of managing and guarding irrigation water, but since there are no funds to pay for the uluulu then nowadays the position is abandoned and only the direct farmer group becomes the managers. The farmer group performs the task of ulu-ulu and also replaces the P3A that should exist for irrigation water management.

Farmers never pay irrigation fees that should be paid for more efficient use of irrigation. Farmers only pay a voluntary fee with an unspecified nominal value at the time of work to clean up the irrigation channel at the time of entering the planting season, but it is only the farmers who do not attend the community work.

One of the problems faced by farmers is the lack of water during the dry season. Farmer groups and Village Governments created a special channel for overcoming it. The special channel was created and connected with Panyindangan Village 
which has springs. The irrigation schedule of each block was made so that each rice field gets water and not drought. Every two times a week the rice fields of each block are given water. In addition to using special irrigation channels, there are also farmers who take advantage of the pool water which they have and are usually located near to rice fields.

Sometimes there is still a dispute between farmers because the water distribution system is less fair even though there is schedule where many farmers who do cheats such as clogging water channels to keep the water flowing into their rice fields. So far the conflict has not been a major and still manageable conflict, but it still harms some farmers whose land is not irrigable.

Respondent Characteristics. Most of the respondents were in the productive age of $58.75 \%$, and $36.25 \%$ of the respondents were 66-75 years old who were older generation but still had high spirits to work despite being elderly. Age of a person is one factor that is closely related to the ability to work in carrying out farming activities and can serve as a benchmark in seeing a person's activity in work where with the age condition that is still productive then a person most likely can work well and maximum (Hasyim, 2006).

Respondents of farmers were mostly men, ie $80 \%$, female farmers were usually farmers who only hire laborers to work on the land. Farming requires high energy, this is what makes some farmers are men.

The majority of respondents had low levels of education because they were stuck with lack of funds to continue their education to a higher level. The majority of respondents' education level was elementary school graduate (SD) that was equal to $65 \%$.

Respondents with the number of dependents who had the largest percentage of $43.75 \%$ only have 2 dependents consisting of husband and wife. This is because their children have worked and have families who no longer live with their parents. As many as $80 \%$ of respondents stated that farming is the main income which means that their livelihood is very dependent on rice farming.

Most of respondents have been farming for a long time, $27.5 \%$ of farmers have been doing rice farming for $41-50$ years. Many farmers who start their farming from adolescence to old age where they know the ins and outs of agriculture in the Buahdua village. But not a few farmers who just started the farming from 1-10 years with a percentage of $13.75 \%$, this is because they continue the farming of their parents and some also make agriculture as a side business.

Farmers' land in Buahdua village is still narrow, indicated from $61.25 \%$ of respondents who owned land with area less than 0.25 ha. This may be indicated that the farmers' land in Buahdua Village is still narrow. The area of owned land can describe the economic condition of farmers. If large land area then the income will be greater when compared with farmers who have a narrow land.

Most of the respondents are the owner of the land that is cultivated was about $66.25 \%$, and for farmers who become cultivators were $33.75 \%$. Farmers get wages in accordance with agreements such as profit sharing called the nengah system.

(Water Rent). The contribution of irrigation water (water rent) can be calculated by using the calculation of farm revenues minus the cost of farming expenses except for the cost of irrigation. Therefore, farm revenues and costs can affect the contribution of irrigation water. Young (2005) stated that the value of irrigation water shows the contribution of water in the agricultural sector.

The value of irrigation water provides something importance at the level of the ability of farmers to pay for irrigation recovery program costs because the contribution value of irrigation water also illustrates the magnitude of non-irrigated income in the rice field farming. 
Table 1. Water Rent Value at Rice Field Agribusiness in Buahdua Village

\begin{tabular}{lll}
\hline Number & Description & Value \\
\hline 1. & Rice production (kg/ha/MT) & 1,288875 \\
2. & Sell cost & 5,000 \\
3. & Acceptance & $6,444,375$ \\
& Cash cost (Rp/ha/MT) & \\
& a. Seed & 23,150 \\
& b.Fertilizer & \\
& Urea & 184,426 \\
Phonska & 201,347 \\
TSP & 67,324 \\
NPK & 30,106 \\
ZA & 3,263 \\
c. Pesticide & 137,338 \\
d. TKLK & 589,625 \\
e. Tractor Rent & 680,663 \\
f. Tax & 82,550 \\
Total Cash Cost & $1,999,791$ \\
Calculated Cost (Rp/ha/MT) & \\
a. Agriculture Tool Depretiation & 4,193 \\
Hoe & 6,610 \\
Sickle & 5,750 \\
b. TKDK & 16,553 \\
Total Calculated Cost & $2,016,344$ \\
Total Cost & $4,428,031$ \\
\hline
\end{tabular}

Source : Primary Data Processed Results.

The amount of water rent indicates how big the value of irrigation water used by farmers to meet the water needs in rice field crops. In the calculation, can be seen that the average acceptance of rice farming in Buahdua Village was Rp. 6,444,375/ha per planting season. In addition, the cost of rice farming will also affect the contribution of the economic value of irrigation water to the total income of the farm (water rent). Total cash cost for rice farming in Buahdua Village was Rp. 1,999,791 and the total cost calculated was Rp. 16,553, so it can be calculated the overall cost to be incurred was Rp. 2,016,344. After the amount of revenue and farming costs in the Buahdua were obtained then the contribution of economic value of irrigation water in the village was $R p .4,428,031$. The contribution value of water was 31.29 percent of the total revenue and is objective if applied to determine the irrigation fee because it also contains the contribution value of irrigation water to the agricultural production. The value of water rent can be used to determine the water irrigation cost which is fair to be applied to the farmers so that the use of irrigation water available can be utilized efficiently so it is sufficient for every planting season.

\section{Willingness To Pay Analysis in determining} water costs. Buahdua village does not have P3A (Farmers Association of Water Users) who usually served to manage irrigation flow into rice fields. Irrigation arrangements are only performed by groups with very simple systems and are rarely free of charge for irrigation repairs. Sometimes there is a dispute between farmers because the water sharing system is not fair where many 
farmers who do cheats such as clogging water channels to keep the water flow into the fields.

Farmers' knowledge of irrigation fees can be said to be lacking, $91 \%$ of farmers were unaware of the actual irrigation water fees they have to pay. They only take advantage of the state of nature that never runs out. Since water is a resource that will always exist, farmers, farmer groups, and the government never make any rules to pay irrigation water fees that irrigate their rice fields. So far there has been no socialization by the government or farmer groups on irrigation fees to farmers so farmers do not know that the irrigation water they use for rice fields has to be paid. Knowledge of irrigation fees is actually very important in determining how much farmers have to pay irrigation water fees. With the irrigation fee, it is expected to use water can be more efficient.

Willingness to Pay is defined as the amount that a consumer can pay to obtain a good or service(Sistyanto \& Hadi, 2012). In determining the WTP, respondents might be asked to select the highest value they are willing to pay for irrigation fees. Therefore it would get the value of WTP from each respondent of rice farmer.

The results showed that $77 \%$ of respondents were willing to pay irrigation fees in the operation and maintenance of the network. There were $23 \%$ who were not willing to pay, many of the reasons they reveal why they were not willing to pay such a presumption that water is a natural product that will always exist.

This research was performed by direct interview with 80 respondents in Buahdua Village. Value of respondents' WTP was varied which starting from the smallest value of Rp. 50,000/ ha/MT to the greatest value of Rp. 250,000/ha/MT. The lowest value was the value paid by farmers who do not participate in community work in irrigation maintenance but they want to participate so they pay to buy cigarettes and food that will be given to the community who perform irrigation cleaning work. The value is not compulsory but voluntary and is an awareness of farmers themselves.

Table 2. Distribution of PAP respondents in Buahdua Village

\begin{tabular}{ccccccc}
\hline No & WTP (Rp/ha/MT) & Frequency & $\begin{array}{c}\text { Land Area } \\
\text { (ha) }\end{array}$ & $\begin{array}{c}\text { Cumulative } \\
\text { Frequency }\end{array}$ & $\begin{array}{c}\text { Relative } \\
\text { Frequncy }\end{array}$ & $\begin{array}{c}\text { Mean } \\
\text { WTP } \\
(\mathrm{Rp})\end{array}$ \\
\hline 1 & 0 & 18 & 5.64 & 80 & 0.225 & 0 \\
2 & 50000 & 20 & 2.29 & 62 & 0.25 & 12500 \\
3 & 55000 & 2 & 0.42 & 42 & 0.025 & 1375 \\
4 & 60000 & 10 & 2.64 & 32 & 0.125 & 7500 \\
5 & 65000 & 1 & 0.28 & 31 & 0.0125 & 812.5 \\
6 & 70000 & 2 & 0.56 & 29 & 0.025 & 1750 \\
7 & 75000 & 8 & 2.87 & 21 & 0.1 & 7500 \\
8 & 80000 & 1 & 0.49 & 20 & 0.0125 & 1000 \\
9 & 85000 & 1 & 0.52 & 19 & 0.0125 & 1062.5 \\
10 & 90000 & 1 & 0.42 & 18 & 0.0125 & 1125 \\
11 & 95000 & 1 & 0.42 & 17 & 0.0125 & 1187.5 \\
12 & 100000 & 6 & 3.34 & 11 & 0.075 & 7500 \\
13 & 120000 & 4 & 2.73 & 7 & 0.05 & 6000 \\
14 & 150000 & 2 & 1.7 & 5 & 0.025 & 3750 \\
15 & 200000 & 1 & 1 & 4 & 0.0125 & 2500 \\
16 & 250000 & 2 & 2.61 & 2 & 0.025 & 6250 \\
\hline & Total & 80 & 27.93 & & 1 & 61812.5 \\
\hline
\end{tabular}

Source : The Result of Processed Primary Data . 
Table 3. Total WTP (TWTP) of Farmer in Buahdua Village

\begin{tabular}{|c|c|c|c|c|c|c|}
\hline No & $\begin{array}{c}\text { WTP } \\
(\mathrm{Rp} / \mathrm{ha} / \mathrm{MT})\end{array}$ & Frequency & $\begin{array}{c}\text { WTP } \\
\text { (Rp/ha/MT) }\end{array}$ & $\begin{array}{c}\text { Sample } \\
\text { Land Area } \\
\text { (ha) }\end{array}$ & $\begin{array}{c}\text { Land } \\
\text { Population } \\
\text { Area (ha) }\end{array}$ & $\begin{array}{c}\text { TWTP } \\
\text { (Rp/ha/MT) }\end{array}$ \\
\hline 1 & 0 & 18 & 0 & 27.93 & 196.4 & 0 \\
\hline 2 & 50000 & 20 & 1000000 & 22.29 & 156.7402793 & 156740279.3 \\
\hline 3 & 55000 & 2 & 110000 & 20 & 140.6373076 & 15470103.83 \\
\hline 4 & 60000 & 10 & 600000 & 19.58 & 137.6839241 & 82610354.46 \\
\hline 5 & 65000 & 1 & 65000 & 16.94 & 119.1197995 & 7742786.967 \\
\hline 6 & 70000 & 2 & 140000 & 16.66 & 117.1508772 & 16401122.81 \\
\hline 7 & 75000 & 8 & 600000 & 16.1 & 113.2130326 & 67927819.55 \\
\hline 8 & 80000 & 1 & 80000 & 13.23 & 93.03157895 & 7442526.316 \\
\hline 9 & 85000 & 1 & 85000 & 12.74 & 89.58596491 & 7614807.018 \\
\hline 10 & 90000 & 1 & 90000 & 12.22 & 85.92939492 & 7733645.542 \\
\hline 11 & 95000 & 1 & 95000 & 11.8 & 82.97601146 & 7882721.088 \\
\hline 12 & 100000 & 6 & 600000 & 11.38 & 80.022628 & 48013576.8 \\
\hline 13 & 120000 & 4 & 480000 & 8.04 & 56.53619764 & 27137374.87 \\
\hline 14 & 150000 & 2 & 300000 & 2.73 & 19.19699248 & 5759097.744 \\
\hline 15 & 200000 & 1 & 200000 & 1.03 & 7.242821339 & 1448564.268 \\
\hline 16 & 250000 & 2 & 500000 & 0.03 & 0.210955961 & 105477.9807 \\
\hline \multicolumn{2}{|r|}{ Total } & 80 & 4945000 & 27.93 & & 460030258.5 \\
\hline \multicolumn{2}{|r|}{ Average } & & 61812.5 & & & 28751891.16 \\
\hline
\end{tabular}

Source : The Result of Processed Primary Data.

WTP mean value was obtained from the calculation based on respondents' WTP data distribution, that was by dividing the number of respondents who pay WTP of i with total number of respondents which then multiplied by the value of WTP.

The mean value of farmers respondents' WTP was Rp. 61,813/ha per planting season. The value indicated the average of respondent's desire to pay irrigation fee per ha for each planting season.

Total WTP (TWTP) of farmers per planting season (MT) can be calculated by obtaining data of the amount of land owned by the respondent and the amount of rice field area of the farmer population. The total area of rice fields owned by respondents in Buahdua Village was 27.93 ha, while for rice field area of the farmer population was 196.4 ha.
The number of respondents' WTP in Buahdua Village was Rp. 4,945,000/ha per planting season with an average value of WTP of Rp. 61,813/ha per planting season. The average value of the PAP indicated the average willingness of respondents to pay irrigation networks that are currently damaged or broken. Total WTP (TWTP) of farmer population in Buahdua Village was Rp. 460,030,259 with average WTP of the population of $\mathrm{Rp}$. 28,751,891. This value indicated that the farmer population's willingness in paying the operation and maintenance fees for each planting season.

If the WTP was paid by all farmers it can be used to repair the damaged irrigation channel and also establish an organization that will manage irrigation. A good irrigation and irrigation organization can certainly make the irrigation arrangement better and run smoothly without any 
conflict and fraud. The determining of the fee is an effective way of improving efficiency for management so that water is always present in every season and the distribution of water is evenly distributed.

Correlation between Water Rent value and Willingness To Payof Farmers. After obtained the calculation of water rent value, it was necessary to compare the value of water rent with the value of the respondent's willingness to pay irrigation operation and maintenance of irrigation network with Willingness To Pay (WTP) approach. WTP of irrigation water only described the wishes of respondents in paying irrigation water fees. The value of obtained water rent value can be used as an approach as irrigation fees.

The value of water rent with the average value of WTP of farmers respondents had been compared, so the researchers suggested that irrigation fee that can be applied in Buahdua Village was Rp. 85,000 that was $1.9 \%$ of water rent value. The value is close to the minimum operating fee and maintenance fees that are often paid by farmers and the average WTP of respondents. In addition, if irrigation fee of Rp. 85,000 multiplied by the amount of land area in Buahdua Village that was 196,4 ha, hence obtained total irrigation fee is equal to Rp. $16,694,000$ per planting season, ie only $3.6 \%$ of the TWTP value. The initial determination for irrigation fee in Buahdua village was Rp. 85,000 and it was considered not to incriminate farmers. The value of irrigation water fees can be used for the operation, maintenance and repair of irrigation networks which are currently damaged so much that it can improve the quality and quantity of rice field production.

\section{CONCLUSION AND SUGGESTION}

\section{Conclusion}

1. The characteristics of the respondents of rice field farmers in Buahdua village have the average age which is still productive and most farmers are male. The last education of the farmer respondents was still low. The dependents number of the families of respondents on average only 2 people, many family members who have been out of the house and was not a dependent. Farming is the main income for most of the respondents, where most have been involved in farming for quite a long time and experienced enough. The average farmer has a relatively narrow land area, the land area can describe the economic condition of farmers. The farming status of the respondents is mostly as the owner's farmer.

2. The average value of water rent in rice farming in Buahdua Village was Rp. $4,428,031 /$ ha per planting season. The value of water rent is the amount of water contribution in rice farming in Buahdua Village and can also be used to determine water fees or irrigation cost which is fair to be applied to farmer.

3. The average value of Willingness To Pay (WTP) of farmers respondents to irrigation water fees was Rp. 61,813/ha per planting season. The value indicated that the average of respondent's desire to pay irrigation fee per ha for each planting season.

\section{Suggestion}

1. The awareness enhancement of farmers in the payment of irrigation water dues.

2. Irrigation fee that can be applied in Buahdua Village is Rp. 85,000/ha per planting season.

3. The importance of establishing an organization that can manage irrigation water in Buahdua Village that has not been formed yet.

\section{Acknowledgment}

The authors would like to thank the head of Buahdua Village and all those who have assisted in this research. 


\section{REFERENCES}

BPS Kabupaten Sumedang. 2015. Kabupaten Sumedang Dalam Angka 2015Sumedang : Badan Pusat Statistik.

BPS Jawa Barat. 2016. Provinsi Jawa Barat dalam Angka 2016. Bandung : Badan Pusat Statistik

Fauzi, A. 2004. Ekonomi Sumberdaya Alam dan Lingkungan.Jakarta: Gramedia Pustaka Utama.

Hasyim, Hasman. 2006. Analisis Hubungan Karakteristik Petani Kopi Terhadap Pendapatan (Studi Kasus: Desa Dolok Seribu Kecamatan Paguran Kabupaten Tapanuli Utara). Jurnal Komunikasi Penelitian. Lembaga Penelitian. Universitas Sumatera Utara, Medan.

Sistyanto, N. A., \& Hadi, M. P. 2012. Penggunaan Air Domestik dan Willingness to Pay Air Bersih PDAM Di Kecamatan Temanggung Kabupaten Temanggung. Jurnal Bumi Indonesia, 1(3).

Sudarma, I. 2015. Harga Air Untuk Irigasi Padi Sawah Di Kabupaten Badung. Bumi Lestari, 15(1).

Umar, H. 2002. Metode Riset Bisnis: Panduan Mahasiswa Untuk Melaksanakan Riset Dilengkapi Contoh Proposal Dan Hasil Riset Bidang Manajemen Dan Akuntansi. Gramedia Pustaka Utama.

Wahyudi, R. Y. 2015. Perubahan Ekonomi Kelembagaan Pengelolaan Irigasi di Kecamatan Asembagus, Kabupaten Situbondo: Studi Biaya Transaksi, Modal Sosial dan Dinamika Pendapatan

Wardani, M. P. 2011. Kajian Strategi Peningkatan Efisiensi Air Irigasi Melalui Metode System Of Rice Intensification Dengan Pendekatan.

Young, R. A. 2005. Nonmarket economic valuation for irrigation water policy decisions: some methodological issues. Journal of Contemporary Water research \& Education, 131(1), 21-25. 